\title{
Hume, os fisiocratas e o nascimento do liberalismo econômico ${ }^{1}$
}

\author{
Didier Deleule \\ Université Paris Nanterre
}

Tradução: Lourenço Fernandes

Desde o ensaio "Do comércio", manifesto inaugural dos Political Discourses (1752), Hume defende em matéria econômica a passagem da "circunstância particular" ao "assunto geral", da "deliberação particular" ao "raciocínio geral". Parece que temos aqui a expressão filosófica de uma passagem histórica, da prática mercantilista do conselho pontual, como manifestação de uma economia ainda dominada por um modelo doméstico: a nação como grande família, a gestão privada como protótipo da gestão dos assuntos públicos, à economia política propriamente dita, na qual o filósofo teria palavra.

Essa passagem requer um termo médio, presente naquilo que por vezes se chama de "naturalismo" humiano, e que pode ser encontrado na reformulação da economia animal no século XviII: ao se separar da vertente iatromecânica, o novo discurso fisiológico e médico fornece certas categorias que permitem perceber o desenvolvimento econômico do corpo social a partir de uma representação orgânica e não mais simplesmente mecânica do corpo biológico. Assim se tornaria pensável o crescimento de um corpo submetido ao imperativo da sobrevivência, cujos elementos ativamente solidários concorrem para a harmonização involuntária do todo. Essa visão — que se depreende da filosofia de Hume — é também a de uma

I Publicado no Bulletin de la Société Française de Philosophie (1980), como "Du domestique au politique: Hume, les physiocrates et la naissance du libéralisme économique". Sessão do dia 22 de Março de I980. O presente artigo, cuja publicação foi autorizada pelo próprio Didier Deleule, atual presidente dessa mesma sociedade, resume o argumento de Hume et la naissance du libéralisme économique (Paris: Aubier, 1979). A revista Discurso agradece a Thiago Vargas, que encaminhou o texto, sugerindo sua publicação. Adotou-se o padrão do original, que, por ser a transcriçãa de uma comunicação oral, não tem notas nem bibliografia. 
das correntes do liberalismo econômico nascente, que, para se implantar, teve de reduzir o obstáculo do esquema artificialista de inteligibilidade da natureza, em particular o teísmo científico derivado do newtonianismo (do qual Cleanto seria o porta-voz nos Diálogos sobre a Religião natural), esquema este que se relaciona à prática mercantilista dos Estados-nação em diferentes níveis: na teoria patriarcal, que sugere a analogia protetor-príncipe/protetor-divino; na doutrina da balança comercial, que sugere a analogia entre constância da quantidade de movimento no mundo/constância da quantidade de riquezas na Europa, e coloca a questão da intervenção voluntarista do Príncipe ou da Providência para a manutenção ou a restauração da dita quantidade; na limitação, enfim, da divisão do trabalho à manufatura, sendo o meio exterior concebido antes como cacofonia violenta que como concerto harmonioso.

Desse ponto de vista, o confronto entre Filo (a hipótese "estratônica" reportada a uma analogia biológica) e Cleanto (o esquema artificialista apoiado numa projeção tecnológica) seria a expressão de duas correntes do newtonianismo que tenderam a difundir seus efeitos a princípio no campo religioso, depois no político e no jurídico, mas também, por fim, no econômico: Hume de um lado, os Fisiocratas de outro. A própria unidade do liberalismo econômico se tornaria, doravante, problemática. Apesar da relativa uniformidade das reivindicaçôes "liberadoras", parece que o fosso se escava entre, de um lado, uma metafísica da ordem que impóe o respeito a uma norma natural, limitadora por essência e instruída pela providência (visão regida, em última instância, pela cumplicidade secreta entre finalismo e mecanicismo), e, de outro, a marcha hesitante de uma espontaneidade cega em seu princípio e anônima em seus efeitos, que exige que a norma, em sua variedade e contingência, seja construída, "inventada", em função das "circunstâncias". Entre o liberalismo de Hume e o dos Fisiocratas, encontra-se a distância que separa a invenção da conformidade. Não simples nuance no seio de uma mesma representação global, mas verdadeira separação, que remete a modelos incompatíveis de inteligibilidade e de ação.

Numa carta de 2I de outubro de I709, Berkeley escrevia a seu amigo Percival: “parece-me que um reino não é uma propriedade, mas um encargo; e não é necessário que a mesma regra governe um Estado, de um lado, os bens fixos e os bens móveis, de outro". Para o filósofo, era essa a maneira de contestar a legitimidade do direito hereditário em matéria de soberania. Em 1752, Hume introduz, no ensaio "Do comércio", uma distinção fundamental entre "circunstância particular" 
e "assunto geral”, "deliberação particular” e "raciocínio geral”. É, para o filósofo, uma maneira de sugerir que o papel de conselheiro do Príncipe não poderia ser atribuído ao negociante ou ao banqueiro, cujo cálculo é necessariamente limitado a uma série de circunstâncias particulares, e cujo modo de pensar, suficiente talvez para assegurar um enriquecimento progressivo ou evitar a falência, revela-se inapto à gestão geral dos assuntos públicos.

As duas precauçôes não se situam exatamente de mesmo nível. A primeira concerne ao monopólio do patrimônio nacional por um indivíduo, à confusão entre interesse pessoal e interesse público, que repousa sobre a ideia de uma comunidade nacional concebida como uma vasta família, ideia de bom grado apoiada em uma teoria de tipo patriarcal: diante da nação, o Príncipe se encontraria na mesma posição que a do pater familias, posição privilegiada, que autorizaria a implantação da autoridade (potestas) sobre os súditos considerados como seus filhos, e a afirmação da posse (dominium) sobre isso que simultaneamente lhe pertence e não lhe pertence propriamente. A segunda precaução tange antes o estatuto do conselheiro: não se deve confundir conselho e receita de governo; mas essa precaução supõe a realização prática do modelo que tende a cercar a gestão das questôes públicas no esquema que anima as questões privadas, de modo que a empresa individual - concebida como protótipo da ação econômica do Estado - leva o Príncipe a considerar que a fertilização dos bens da nação passa pelo mesmo desvio que a fertilização dos bens de uma empresa privada.

Essas duas precauçôes definem, na verdade, os dois aspectos complementares da prevalência tenaz do modelo doméstico em economia política, apesar de todas as objeções a ele feitas ao longo do século.

Minha intenção é mostrar que a supressão do modelo doméstico na ordem política é parte não apenas da substituição da suserania pela soberania, do senhorio pelo Estado soberano, mas que essa substituição deve ser prolongada e efetivada no plano econômico e social, pelas reivindicaçóes "liberais" nascentes. A passagem do doméstico ao político (do ponto de vista particular ao ponto de vista geral) é singularmente convocada pela exigência de "libertação" das forças econômicas.

Corolário: a desconfiança em relação ao poder político (o Estado, o Estado de direito), considerado como característica do liberalismo econômico em sua aurora, não deve ser confundida com uma desconfiança em relação ao Estado em geral, em proveito de uma simples apologia dos mecanismos espontâneos da sociedade civil, mas antes, como crítica mordaz das práticas mercantilistas do Estado-nação, na medida que essas práticas (proibicionismo, protecionismo, belicismo) destroem o alvo que pretendem alcançar, a saber, o enriquecimento da nação como condição do enriquecimento dos particulares, como se ao chefe 
supremo coubesse a manutenção de uma empresa doméstica. Desse ponto de vista, o liberalismo econômico não demove o Estado de suas funções; ele as reflete, e busca redobrá-las.

É provável, com efeito, que a soberania tenha deslocado a suserania, em vez de aboli-la. O advento da soberania, ligada ao poder absoluto, tem certamente como objetivos a paz, a segurança, a substituição da força pelo direito. Mas, como mostraram entre outros, Koselleck, essa iniciativa é estreitamente solidária à vontade de pôr fim às guerras civis, às guerras de religião, ao confronto de facções. É a esse título que a autoridade da lei deve ser encarnada na Razão de Estado. Face ao exercício do direito (privilégio, direito do mais forte), a lei tem caráter de obrigação: ela constrange, submete: para salvaguardar (a vida), para preservar (a propriedade). Essa obrigação acarreta, para o chefe supremo, uma relação de proteção e de obediência.

Além disso, a paz civil tem como preço o conflito permanente (aberto ou em germe) entre nações. A ordem europeia repousa sobre o relativo equilíbrio nacional da balança comercial (outra versão, sob certos aspectos, do equilíbrio do sangue derramado), porém no quadro da representação de um estoque finito de riquezas, que limita a concorrência ao exercício da rivalidade, ou da "inveja" [jealousy] (jogo de soma zero).

O soberano endossa assim certas miragens da suserania. No interior de cada Estado, permanece a relação de dominação: dominação da lei, sem dúvida, mas na medida em que ela representa a expressão da vontade do soberano (qualquer que seja a natureza deste); e, também, manutenção do dominium, que, embora não mais reflita a relação romana entre senhor e escravo, inclui a perspectiva de uma delegação dos bens (ver, por exemplo, o édito de Luís XIv, de agosto de I692, no qual o Príncipe é considerado como o suserano universal, "verdadeiro proprietário dos bens de seus vassalos", aos quais cabe apenas o domínio útil). Mas é sobretudo nas relações externas que essa miragem permanece, pois a soberania afirmada afasta o estado de guerra através da posse das armas (imperium).

Com o advento da soberania, teria havido, portanto, um duplo deslocamento da suserania. Quanto ao conteúdo, com uma nova maneira de dominium que confere jurisdição sob uma forma diferente daquela do contrato feudal; quanto ao lugar de seu exercício, com a transferência do imperium, nas relações entre nações, para o monopólio das matérias-primas e a abertura dos mercados para os produtos manufaturados. Lembremo-nos de Montchrestien, comparando os Estados a corpos esfomeados que, através do comércio, tentam se saciar com a substância uns dos outros. 
Vistas as coisas de perto, esse deslocamento da suserania pela soberania foi precisamente aquilo que os pioneiros do liberalismo econômico responsabilizaram pela política "mercantilista" dos Estados-nação. Se os golpes desses críticos são dirigidos contra medidas práticas (protecionismo, proibicionismo, estratégia de guerra), também o são, na teoria, à inadequação de um modelo doméstico ao campo da política econômica. Ora, esse tipo de contestação não advém de um simples debate econômico de caráter técnico, mas manifesta também - e é isso que eu gostaria de mostrar — um problema verdadeiramente filosófico.

A passagem do estudo das circunstâncias particulares ao raciocínio sobre assuntos gerais (exigida por Hume desde o começo dos Political Discourses) implica a tomada de consciência de um deslocamento fundamental, do antigo modo de gestão, cujo correlato é um conceito de economia referido a uma técnica ético-administrativa e não a uma reflexão sobre os modos de produção, à consideração dos elementos solidários de uma totalidade produtiva sob a forma da agricultura, do comércio e da indústria. O modelo da economia doméstica revela-se inadequado à apreensão dos fenômenos econômicos globais que, segundo Hume, caracterizam o período histórico recente, distinto de qualquer situação anterior, e que exige, em consequência, um novo instrumento de análise, diferente dos esquemas herdados da Antiguidade. A medida dessa relatividade histórica dos modos de produção é dada, por exemplo, em uma passagem do ensaio "Of the Populousness of Ancient Nations": "Não me lembro de nenhuma passagem, em qualquer autor antigo que seja, na qual o crescimento de uma cidade seja atribuído à instalação de uma manufatura. O comércio que atualmente floresce consiste principalmente na troca de produtos convenientes a diferentes climas e solos".

As descobertas científicas e técnicas, as novas perspectivas geográficas e a facilitação dos meios de comunicação escavam um fosso, aos olhos de Hume, entre o desenvolvimento moderno da indústria e do comércio e a economia antiga, que, regida por outros costumes, assegurava a potência do Estado ao custo da ausência de indústria e de luxo. É impossível, portanto, retornar às "máximas da política antiga", o que implica, por seu turno, a impossibilidade de manutenção da economia doméstica como modelo da economia política. Ora, desde Bodin, o pensamento político moderno instituíra uma continuidade do modelo doméstico: "república é o justo governo de várias habitações [mesnages], e daquilo que lhes é comum, com potência soberana [...] Habitação é um justo governo de vários súditos, sob obediência de um chefe de família e do que lhe pertence"; ou ainda Mun: "com o tesouro de um reino, passa-se o mesmo que com o bem de um particular que, tendo grande quantidade de mercadorias, nem por isso abandona o comércio e todos os dias aplica o dinheiro que lhe resta para adquirir ainda 
mais mercadorias"; sem mencionar a analogia entre família e nação, retomada de maneira lancinante nos escritos políticos ingleses dos séculos XVI e XVII, da qual a teoria patriarcal de Filmer é o exemplo acabado.

Ora, se a teoria patriarcal, em sua vocação de justificativa cronológica e lógica da monarquia, permite reforçar o sistema da economia doméstica a ponto de fornecer suas bases ideológicas ideais, convém notar que o modelo não é de forma alguma anulado pela construção de uma representação mecânica e artesanal da ordem natural. É assim que a destruição lockiana da teoria patriarcal não leva a pôr em causa a legitimidade natural do poder paterno, apenas sua limitação no tempo, até que a criança tenha acesso à idade da razão, no momento em que, com o desenvolvimento conveniente de suas potencialidades, o ser humano é reputado conhecer por si mesmo a estrutura da ordem natural. A cultura da disciplina intelectual é substituída aqui pela manutenção autoritária e transferida ao poder político da disciplina familiar; mas, nos dois casos, uma ordem "natural" imposta ou reconhecida ultrapassa a eficácia da ação na compatibilidade exigida da regulamentação e da liberdade. Desse ponto de vista, a ordem artificial da regulamentação e a ordem natural da liberdade chegam ao mesmo ponto: a impossibilidade de pensar a máquina econômica e social de outra forma que um mecanismo regulado do exterior, unidade afirmada, porém problemática, de múltiplos mecanismos, submetidos a seus próprios regimes de interação, em busca de uma harmonia decretada, a um só tempo almejada e incerta, voluntariamente afirmada, mas que poderia ser espontaneamente invalidada, pela ausência de solidariedade ativa entre os elementos componentes.

Resultam daí três séries de apontamentos:

I. O mercantilismo, na época de Locke, é menos obsedado pelo metalismo do que pela preservação da balança comercial. A noção é em parte derivada dos métodos da aritmética política, que, além dos trabalhos de ordem estatística, tende a construir por número, peso e medida as preocupações do Estado sobre o modelo das preocupaçōes individuais. Assim como o indivíduo busca a cada ano equilibrar seu orçamento, o Estado deve fazer o mesmo, ao cuidar em obter o equilíbrio de sua balança comercial, condição de sua manutenção e saúde. "Um reino", diz Locke, "enriquece ou empobrece da mesma forma que um fazendeiro". Qualquer que seja, aliás, a polêmica contra a teoria patriarcal, com a reivindicação da propriedade individual em lugar da propriedade real, na separação do poder político e do poder paterno, a instalação de uma ordem natural inscrita numa estrutura teleológica permite apreender, no quadro do liberalismo político nascente, a continuidade da economia doméstica ligada aqui a medidas de tipo mercantilista. L. Stephen sublinhou a ambiguidade da fórmula de Locke; de 
um lado, pode-se considerar como estabelecido que um fazendeiro e uma nação prosperem juntos graças à temperança e ao esforço; se está aí o sentido da frase, nada de muito original. Mas, de outro lado, se Locke quis dizer, como é mais provável, que uma nação empobrece da mesma forma que um fazendeiro, isto é, gastando mais do que recebe, e se essa observação significa que um fluxo de dinheiro para o exterior empobrece uma nação da mesma forma que um excesso de despesas sobre as receitas empobrece o fazendeiro, Locke continuaria assombrado pelo medo quimérico de uma diminuição da poupança acarretada por um afluxo do numerário, enquanto (mesmo no caso do fazendeiro) é preciso se precaver a não confundir poupança e entesouramento. Ao considerar toda despesa como o contrário da poupança, Locke toma como diminuição dos recursos naturais o que representa simplesmente uma troca de excedente. A obsessão pela "circunstância particular" põe obstáculo aqui à abordagem do "assunto geral", e se pode compreender porque a destruição do mito da balança comercial é, aos olhos de Hume, a tarefa mais urgente do filósofo-economista: ponto nodal da prática mercantilista, a noção de balança comercial, protegida pela teoria patriarcal ou pela teoria da ordem natural, é também a expressão mais clara do triunfo da circunstância particular promovida ao nível de assunto geral.

2. O sistema da balança comercial não se revela de forma alguma incompatível com a reconstrução da ordem natural a partir de um esquema artificialista de inteligibilidade: seja essa ordem evidentemente percebida ou racionalmente deduzida, sua incidência possível sobre a análise dos fenômenos econômicos faz dela um obstáculo à necessidade "naturalista" de pensar o crescimento de um corpo e sua organização problemática, mas espontânea. A fixação geral de um modelo mecânico simples leva à representação do corpo social como uma máquina acionada do exterior pelo príncipe encarregado, tal como a vontade divina face a suas criaturas, mas também como o manufaturador face a seus artesãos, de vigiar a repartição das tarefas entre seus súditos e de velar, enquanto proprietário, coproprietário ou simplesmente gestor dos bens da nação, pela harmonização dos mecanismos de produção no interior da nação a fim de fazer frutificar as riquezas comuns, assim como na conservação da quantidade de moeda ou de bens nas relações com as outras nações. O príncipe, como o empreendedor divino e o empreendedor privado, deve, através de sua política, manter a constância de uma quantidade dada e, quando esta última tende a diminuir, tentar restaurá-la por todos os meios em seu poder: sob esse aspecto, pôr em prática medidas protecionistas e proibicionistas é, no voluntarismo político que as anima, um pouco o análogo da intervenção contínua da providência na restauração da quantidade de movimento no universo. Mas, ao mesmo tempo, a divisão do trabalho 
encontra-se espacialmente limitada à manufatura, na harmonia suposta da busca privada pelo lucro e pelo poder do Estado, desde que são reunidas as condições ideais de abundância de mão-de-obra e de abundância do dinheiro destinado ao mesmo tempo a facilitar o financiamento das empresas privadas e a força do Estado. Assim como a política econômica nacional é construída sobre o modelo da gestão privada, a representação da economia do universo é, do mesmo modo, construída a partir do modelo tecnológico da ação humana sobre a natureza; hipóstase da arte humana, o argumento do desígnio apreende finalmente a ordem natural somente como cópia do processo mecânico artificial. $\mathrm{O}$ arquiteto divino aparece também como uma derivação conceitual do artesão, mas igualmente do engenheiro, do empreendedor, do legislador ou do monarca. Em todo lugar em que surge uma vontade capaz de dar forma ao projeto que ela mesma concebeu, o arranjo mecânico dos elementos, sustentado pelo decreto inicial, compóe uma totalidade externa cuja finalidade escapa por natureza aos componentes para se transportar inteira para a "cabeça" do organizador. O lucro do negociante sugere o lucro da nação; a balança é sua imagem obrigatória. O produto artesanal sugere o produto divino: o relógio, o edifício, o aparato mecânico, a máquina se tornam sua representação privilegiada. Equilíbrio, ajuste e adaptação dos meios aos fins se unem num trabalho de montagem que supõe ao mesmo tempo um projeto, um plano, um construtor, uma escolha enfim entre as diferentes séries possíveis de objetos manufaturados em função da qualidade prevista do produto e do benefício que dele se pode tirar. Sem dúvida, é por ter apreendido nessas falências a lógica da argumentação, que Hume sugere ironicamente, nos Diálogos, a fábula de uma repartição de tarefas entre os artesãos divinos contra os que persistem em considerar a divisão do trabalho como uma conveniência comandada pela providência do exterior, mais do que como a solução de um problema vital colocado para a espécie humana.

3. Na perspectiva estrita da divisão do trabalho na manufatura, em que a produção é exclusivamente submetida aos imperativos nacionais, o eventual crescimento do corpo social de inclinação produtiva é impensável fora de um reequilíbrio das forças face à ameaça exterior; mesmo assim, esse reequilíbrio acarreta menos um crescimento propriamente dito que uma simples subsistência, mantida ao preço de uma luta corpo a corpo no seio de um negócio internacional em que a soma das riquezas se revela quase constante. Além dos fatores "objetivos", como a falta de moeda de uma certa época, que são sempre interessantes de analisar, a crítica humiana da "inveja comercial" [jealousy of commerce], inseparável das noções de parcialidade e de comparação, põe o acento sobre uma outra forma de prazer, em que o cálculo utilitário encontra seu lugar no espaço reservado de um 
excedente de prazer posterior. Da dificuldade do prazer imediato, que gasta brusca e espetacularmente o que foi pacientemente acumulado, à possibilidade de prazer diferida na rentabilidade dos investimentos, da figura histórica e quase mítica do grande senhor dispendioso à do negociante moderado, marca-se a distância da incerteza (suspensa numa ameaça de morte) à segurança (como a anulação de uma morte por sufocamento) pelo intermédio de um estratagema de produção e de troca internacional suscetível de fornecer primariamente um a mais que inaugura um crescimento indefinido. Nessa outra lógica, para que o crescimento do corpo social de inclinação produtiva seja liberado, é necessário que a mediação do jogo de oferta e demanda intervenha sobre um mercado internacional. Tendo a divisão internacional do trabalho se tornado a condição da satisfação nacional e de seu desenvolvimento, a mudança do ponto de vista no modo de prazer (e, correlativamente, na definição da produção ótima) é ali ainda assumida pela passagem da consideração da "circunstância particular" ao interesse prioritariamente atribuído ao "assunto geral". Nesse sentido, a figura do negociante-empreendedor, primeira figura histórica do corpo produtivo, enquanto intermediário doravante percebido como parasitário no corpo corporativo em que se efetuava a primeira cisão, aparece de fato como o mediador ativo da transformação na medida em que sua atividade, por sua própria natureza, ultrapassa o quadro estreito da nação, e que seus interesses próprios têm, de saída, vocação internacional. Sem outro privilégio além de sua própria posição, o negociante, antes aventureiro e doravante empreendedor, manifesta, apenas por sua presença, o absurdo das medidas protecionistas e proibitivas no comércio internacional, já que o equilíbrio automático das trocas torna vã a busca por uma balança favorável.

Ora, essa vocação internacional faz parte precisamente das queixas que os Fisiocratas entretêm diante das profissōes comerciais, quaisquer que possam ter sido as hesitações iniciais de Quesnay sobre o eventual estatuto produtivo do comércio exterior. Mas essa desconfiança, longe de levar os Fisiocratas a acentuar a regulamentação, os conduz, ao contrário, em acordo com o sistema da ordem natural, a reivindicar a liberdade das trocas. A crítica fisiocrática ao dogma da balança comercial repousa, com efeito, sobre a ideia de uma ação violenta, contra a natureza, que arrisca paralisar a riqueza das naçóes. Todavia, como o comércio exterior não é considerado produtivo, a liberdade proclamada concerne essencialmente à exportação dos grãos destinada a manter um bom preço. De resto, o comércio é um mal necessário, um mal menor que contribui sobretudo para enriquecer os negociantes às expensas dos trabalhadores produtivos e só se torna realmente oportuno em caso de superabundância ou superpopulação. Vê-se a distância que separa Hume dos Fisiocratas: para estes últimos, o eventual equilíbrio 
do comércio exterior tem valor apenas contábil; se fornece um ganho, não pode criar riqueza alguma. Ao contrário, segundo Hume, o aumento do volume das exportações suscita um crescimento da produção no país exportador.

Diferentemente dos Economistas, que enxergam a produtividade apenas na colaboração da Natureza e da classe agrícola, sendo a Natureza uma mera provedora de riquezas, Hume póe o trabalho, e apenas o trabalho, na fonte de toda riqueza, e vê o crescimento da produção como a ação solidária das classes produtivas, isto é, tanto os artesãos e os comerciantes quanto os agricultores. Do ponto de vista do modelo geral, a diferença é decisiva, pois se o fetichismo da Natureza engaja os fisiocratas a recusar estatuto de riqueza ao dinheiro, leva-os igualmente a negar o poder criador do trabalho humano, a instalar uma segregação entre as diferentes classes da nação (produtiva-estéril) e a perceber a reconstituição do produto líquido seguindo um encaminhamento diferente da realização dos lucros comerciais e industriais, eles mesmos concebidos, enquanto resultado de um transporte ou de uma transformação, como desvio contingente de uma parte do produto líquido na ausência de toda criação de valor. No mesmo movimento, a realização do desígnio da Natureza implica que a ordem social seja adequada ao que deve ser por essência, isto é, uma harmonização voluntariamente instruída pelo Autor da Natureza e que cabe ao soberano, imagem da divindade, fazer respeitar, ao mostrar que nenhuma harmonia natural entre os interesses das classes sociais é possível se se incluem as classes "estéreis" (industriais ou subornadas) no concerto produtivo. A finalidade introduzida de fora na máquina econômica, ao pôr o acento sobre a generosidade da Natureza, leva a mutilar dois dos membros do corpo, mesmo se sua prestação social não é posta em questão, já que os serviços prestados à coletividade pelos comerciantes e industriais são sublinhados no mesmo momento em que lhes é negada qualquer capacidade produtiva. É assim que as tendências liberais, na medida em que se encontram tomadas nas redes de um plano definido que escapa aos atores, mas elaborado pela providência, juntam-se (quaisquer que sejam seus méritos próprios e sua importância histórica) a um horizonte bastante análogo ao que desenha a autoridade estatal na condução da máquina econômica, arranjada por medidas artificialmente impostas em vista de um equilíbrio desejado. Aqui e ali, com efeito, o plano é transferido dos atores ao construtor ou ao gerente; nos dois casos, quer se fale a ordem natural ou se instale o artifício deliberado, a solidariedade só pode ser mecanicamente comandada ou restaurada por um agente externo, mas implicado a título de interesse (poder ou propriedade) no funcionamento do conjunto, não sem que, no corpo social, certas forças produtivas se encontrem valorizadas em detrimento de outras. 
A perspectiva humiana, ao contrário, tem por ambição afirmar a solidariedade ativa dos elementos com seu corpo defensor. A harmonia involuntária dos interesses é em Hume apenas a contrapartida de um esvaziamento total de finalidade, já que a responsabilidade consciente dos atores não é em momento algum reivindicada, e trata-se menos de substituir uma finalidade interna deliberadamente assumida a uma finalidade externa espoliadora e frustrante que de afirmar a ausência total de finalidade voluntária. Em lugar da construção prevista e dirigida ou orientada, da natureza refletida no artefato que lhe dá a medida inteligível, afirma-se a espontaneidade cega, não-refletida, movida apenas pela exigência de sobrevivência e investida, através do corpo social, no debate contraditório das paixões humanas, tendo, sob pressão de múltiplas causas eficientes de ordem essencialmente "moral", dado nascimento, num período relativamente recente, a uma forma nova de vida econômica que nenhum modelo doméstico ou artesanal pode apreender pertinentemente na complexidade de sua ascensão. O "liberalismo" de Hume não é mais o do laissez-faire, mas do laissez-croître; não incide nas engrenagens de uma máquina bem lubrificada, mas nos órgãos de um corpo vivo. Posto que o discurso médico se encontra então em plena revolução, a linguagem requerida não é mais a da interação, mas da higiene, a liberdade em questão não é mais a do movimento das máquinas, uma vez dada a corda inicial, mas a do curso natural de um crescimento no processo dinâmico de jogo recíproco dos órgãos, quando este não é nem entravado pelo arbitrário da gestão burocrática nem ferido pelas intervenções "naturais" daqueles que, na ausência de qualquer perspectiva histórica, não podem apreender sua sinuosa e caótica via.

Hume mantém, portanto, a analogia entre o corpo social e o corpo individual, mas o corpo é doravante percebido, senão como um organismo, ao menos como um processo combinatório de partículas elementares movidas por afinidade, atração, simpatia, que, na associação assim formada, excede qualquer redução a uma descrição mecânica simples. Mais que autômato, ou seja, a figura animada do exterior que dá aparência de vida autônoma, o corpo é organização espontânea, inventividade regulada por exigências vitais, solidariedade ativa dos elementos constituintes (sem a qual a subsistência seria posta em perigo), estrutura harmônica, mas frágil, produzida pela interação dos componentes. Mas o corpo só existe e subsiste por essa interação, sua implementação no tempo é submetida a esse imperativo. E, se não é outra coisa, além da coleção desses elementos, é suficiente que um deles cesse sua ação para que o todo desabe como um castelo de cartas. Detendo sua existência um incessante movimento que o anima e que lhe permite cumprir seus ciclos sucessivos, a preguiça ou a extinção em qualquer lugar que seja de um desses agentes é suficiente para ameaçar sua sobrevivência. 
É portanto a natureza que, para perseverar, suscita o artifício. Se, em conformidade ao preceito hipocrático lembrado por Sydenham, é preciso antes ajudar a natureza que contrariá-la, então ajudar a natureza — eis toda a ambiguidade do liberalismo nascente - é nada fazer, deixar a natureza fazer, não intervir. Mas isso também pode se mostrar, eventualmente, artificial, quer dizer, é preciso saber quando é preciso opor a natureza a si mesma em nome do interesse superior da sobrevivência. Certamente, o pensamento liberal clássico, assim como o pensamento médico, com o qual ele compõe um bloco, denuncia todas as formas de violência impostas ao curso natural das coisas: as proibições e as medidas ditas protecionistas vão de encontro aos interesses naturais, e conduzem ao que Dudley North chamava uma "aberração política"; às limitações e às proibições devem-se substituir a abstenção ou a facilitação; a arte concebida como antinatureza deve ceder o lugar à própria natureza ou à arte concebida como auxiliar da natureza. Uma frase frequentemente citada de Petty dá a medida dessa mudança de atitude: "devemos considerar em geral que, se os médicos mais sábios não se intrometem demais no estado de seu paciente, observando e seguindo os movimentos da natureza mais do que os contradizendo, ao administrar seus violentos remédios, deve-se agir de acordo em política e em economia."

Não se intrometer demais no estado do paciente quer dizer não fazer nada que arrisque agravá-lo. Mas, uma vez admitida essa constatação elementar, é ainda possível, de fato, nada fazer ou fazer algo, por pouco que seja. E essa dupla possibilidade, às vezes confundida em uma visão grosseira do liberalismo, apenas pode funcionar a partir de dois modelos muito diferentes.

Quanto à coerência da obra de Quesnay, é verdade que o modelo circulatório posto em jogo no Tableau économique conduz à descrição de um estado estacionário ou médio no qual a ordem econômica supõe a reconstituição do mesmo; dito de outra forma, a igualdade da receita anual em curso e da receita do ano precedente. Desse ponto de vista, a terra, único poder realmente produtivo dotado de inexaurível fecundidade, garante a reprodução ininterrupta do corpo social, desde que o trabalho humano colabore à sua produção de valor, e que os avanços (fundamentais, primitivos e anuais) assegurem essa produção de valor. Uma tal perspectiva fixista, destinada a preservar a estabilidade mais que a permitir a evolução, torna problemático um eventual crescimento. O esquema ideal seria o do "estado de prosperidade de um reino cujo território seria levado a seu mais alto grau possível de cultura, de liberdade e de facilidade de comércio e onde por conseguinte a receita dos proprietários não poderia mais crescer" (Quesnay). Uma tal visão implica duas consequências. 
I. Se o estado estacionário não pode, por definição, ter crescimento, ele pode, em contrapartida, ser ameaçado pelo desperdício; é assim que uma série de aquisições supérfluas, pela classe estéril, acarreta, para os proprietários, um aumento do luxo decorativo que pode provocar um empobrecimento da nação em geral. Da mesma maneira, o imposto indireto engendra uma série de "danos", de "deterioraçōes" que, ao multiplicar as fortunas pecuniárias advindas dos lucros do comércio e da indústria, se traduzem por uma inversão da circulação do dinheiro, um bloqueio do processo de reconstituição e, portanto, a destruição pura e simples da ordem natural, por substituição do investimento necessário à agricultura, única fonte de reprodução anual de riquezas, pela acumulação monetária. Existe portanto, segundo a expressão do Sr. Lutfalla, uma "patologia" do Quadro econômico que tende a mostrar os perigos de uma ruptura do equilíbrio capaz de pôr fim ao movimento perpétuo do ciclo produtivo.

2. Basta, todavia, que os proprietários comprem mais da classe produtiva que da classe estéril para que esse acréscimo de despesas seja "visto como uma adição aos avanços desta classe", e, portanto, como a possibilidade aberta de uma melhoria das terras ou mesmo como expectativa de um crescimento do produto líquido. Isso significa que o crescimento não é totalmente excluído do Quadro; mas, longe de ser um processo natural e necessário, depende apenas do decreto da classe dos proprietários (e do soberano enquanto coproprietário) e de sua benevolência. Nesse sentido, representa o aspecto positivo da patologia do Quadro econômico, na medida em que, tanto quanto o desperdício, introduz uma ruptura na revolução circular, mesmo se contribui para a consolidação da propriedade. Parece assim que as outras classes sociais, longe de participarem organicamente no desenvolvimento do sistema produtivo, são reduzidas quer ao estatuto de instrumento (é o caso da classe agrícola, única classe produtiva, quer ao papel de auxiliar (caso da classe estéril), sem que lhes seja reservado, no quadro da ordem natural, qualquer margem real de decisão. Apenas os que gozam das riquezas (os proprietários), sem produzi-las nem prepará-las, têm a possibilidade, em função da natureza dos "avanços" concedidos, de fazer oscilar a balança num sentido ou no outro.

Nessa perspectiva, afirmar que Il mondo va da se (para retomar a expressão de Quesnay) quer dizer então que a livre concorrência conduz ao melhor preço, indo assim no sentido do interesse das diferentes classes, desde que se encare o estado ideal médio como modelo da circulação dos bens no interior do corpo social, sob o controle de uma "autoridade tutelar e soberana" que garante o reconhecimento da ordem natural pela conformidade de suas leis. Mas não é da natureza do corpo produtivo crescer, se não indefinidamente (nem Hume nem os Fisiocratas pensam assim), ao menos relativamente e, sobretudo, espontaneamente. $\mathrm{O}$ crescimento 
fisiocrático se assemelha mais a uma adição do que a um verdadeiro desenvolvimento. Iniciado mecânica e artificialmente, encorajado ou detido a bel-prazer de uma vontade particular, não se poderia encará-lo como a consequência imediata de uma dependência mútua dos órgãos do corpo. A liberdade das engrenagens é uma mecânica regulada em definitivo, idealmente fixada num esquema circulatório em que, na ausência de um jogo espontâneo dos órgãos, todo desvio se torna patogênico. Deixar que a natureza conduza quer dizer deixar que a propriedade se conduza rumo ao melhor de seus interesses, que se confundem com o interesse geral da nação sob o signo da ordem natural.

Não surpreende, portanto, que Smith, na esteira de Hume, critique Quesnay por ignorar a espontaneidade do corpo vivo e ter finalmente querido exercer, em nome da ordem natural, uma restrição dietética sobre o corpo social. Pois a ordenação unidimensional da medicina fisiocrática se opõe à variedade das situaçôes concretas às quais o corpo é chamado a reagir, de maneira totalmente hipocrática, por mecanismos de defesa cujas vias não foram balizadas preliminarmente por qualquer instrução ou programação. Já sugeri que Hume criticava no mercantilismo menos a imoralidade ou o artifício de sua cadeia de medidas coercitivas que sua relativa ineficácia, e o risco que elas comportam de frear a atividade econômica em seu desenvolvimento recente ao enfraquecer o espírito de empresa. A experiência imaginária sugerida no ensaio "Da balança do comércio" visa precisamente pôr em evidência a inutilidade das proteções e proibições pela descrição do processo de restabelecimento automático das trocas. Assim como a água, onde quer que se espalhe, sempre reencontra seu nível, igualmente o corpo social se ajusta espontaneamente, mesmo na ausência de uma liberdade perfeita, a seu ambiente.

Ora, a exigência freia, mas não anula. Assim como a natureza, por sua força inerente, interrompe a apraxia à qual o pirronismo conduziria logicamente, também as possibilidades de adaptação do corpo social em seu esforço de conservação são tais, que, até certo ponto, a solidariedade que de fato lhe rege o funcionamento permite a manutenção de sua coesão na instauração do necessário artifício da troca, apesar da ação contrária de certos artifícios paralisantes. A noção essencial aqui é a de reparação, que reenvia às de simpatia e de harmonia involuntária: contra os mercantilistas, ela significa que não há perda absoluta, que o princípio do jogo de soma zero é impotente para dar conta do funcionamento de um corpo vivo (individual ou social), que a compensação, em seu dinamismo mesmo, age espontaneamente em todos os níveis, para restabelecer um equilíbrio relativo suficiente para garantir a sobrevivência. Mas, contra os Fisiocratas, a noção de "reparação" significa que a circulação não é pura e simples revolução estabelecida 
segundo o esquema ideal do retorno do mesmo, em função de um regime rigoroso; ao contrário, a velocidade maior ou menor do processo impede a fixação de uma norma de saúde, princípio regulador com relação ao qual se seria convocado a estabelecer o quadro como uma patologia do corpo social. O desvio não é o signo sensível de uma doença, mas a marcha natural de um ciclo perpétuo de trocas constantemente renovadas em meio ao qual o equilíbrio, sempre precário, não cessa de ser restaurado com maiores ou menores gastos na composição complexa e variável dos elementos, em função das "circunstâncias". A norma, longe de ser dada de uma vez por todas, se inventa a si mesma continuamente, sob a pressão do ambiente, na aptidão do corpo a "reparar" as perdas; e isso fora do alcance de todo controle burocrático, de uma intervenção da providência, de qualquer vigilância despótica legal.

Portanto, em vez do Deus-arquiteto e artesão que ordena a cadeia dos seres como o príncipe ordena as tarefas de seus súditos ("superintendente da indústria dos particulares", para retomar a expressão de Smith), ou do empreendedor que ordena a divisão do trabalho no interior da produção manufatureira, o que a harmonia involuntária de fato substitui, na visão do processo, é o voluntarismo do soberano ou do proprietário. Em Cleanto, como no sistema fisiocrático, a ordem é o produto de um desígnio, de uma vontade alinhada a uma representação; o produto reconhecido se torna ao mesmo tempo o signo do desígnio e sua expressão; daqui, o natural acede à dignidade de essencial; a confusão natureza-essência apenas recorta a confusão natureza-desígnio denunciada por Filo; e é nessa confusão que a projeção técnica alcança toda a sua amplitude. O mundo apreendido como um conjunto de produtos, primeiro concebidos e depois realizados, reenvia à necessidade de um mestre de produção, arquiteto pela concepção do plano, e a vigilância sobre sua realização, artesão pela fabricação de peças, por seu ajuste preciso e pela vigilância mantida para sua boa coordenação. Por exemplo, a necessidade da divisão do trabalho, reconhecida por Hume como primeira solução ao problema econômico da sobrevivência, não conduz o filósofo a projetar seu esquema na constituição da economia do mundo. A divisão do trabalho é, como a propriedade, evento contingente, no sentido de que sempre é possível imaginar uma outra distribuição de cartas, a partir da qual a emergência factual destes fenômenos sociais não teria tido significação alguma. Mas tais eventos contingentes se tornaram urgentes, a título de soluções vitais, na contradição dos efeitos antropológicos e econômicos de uma causalidade natural mas cega, e sua urgência impõe a necessidade. Da mesma maneira, o crescimento recente do corpo produtivo no interior do corpo social em favor de "circunstâncias" múltiplas supõe que se deem os meios de pensar o fato e se renuncie a toda perspectiva doméstica 
ou técnico-mecânica na apreensão global de um fenômeno que nos coloca de saída no registro de uma dimensão internacional em vias de organização. Desse fenômeno, nem a balança, nem o moto perpétuo são aptos a dar conta, a primeira porque concebe o equilíbrio apenas como um sistema estático de oposição, o segundo porque percebe o equilíbrio apenas como um estado ideal a ser preservado. Apenas os índices fornecidos pela economia animal renovada permitem pensar o crescimento de um corpo como uma sucessão de equilíbrios parciais e dinâmicos, como uma organização espontânea de elementos solidários ativos movidos por um concurso necessário de causas eficientes. Hume talvez não seja o primeiro a denunciar o triunfo da "circunstância particular", mas é sem dúvida o primeiro que dá os meios de refletir, através do conjunto de sua obra, sobre modalidades de abordagem daquilo que ele mesmo chama de "assunto geral". Natura medicatrix, certamente, na medida em que o artifício se põe a seu serviço, mas na medida que um ciclo de trocas generalizadas ultrapassa sua eficácia, que a perturbação de um único elemento basta para gerar turbulência na economia do todo e na qual, reciprocamente, toda despesa pode ser compensada por uma espontaneidade reparadora. Sob esse aspecto, apenas a mudança do modelo pode, em sentido estrito, libertar o corpo produtivo, e não somente a suspeita já exercida por outros ou a luta engajada aqui e ali contra as aberraçôes protecionistas, o que Smith chama de "prescrições absurdas do médico". O ganho essencial trazido por Hume resume-se a isto: a junção das inclinaçôes libertadoras e do modelo que permite abordá-las.

Tal é o "naturalismo" de Hume; tal é também seu "liberalismo". A crítica dos entraves, dos embaraços, das limitações absurdas não é convocada contra uma Natureza cuja ordem providencial não poderia sofrer a intervenção perturbadora da mão humana e de sua arte. Uma vez postos em lugar os "remédios" fundamentais (as regras da justiça), o corpo social pode se desenvolver nas diversas direçôes cuja expressão política são as diferentes formas de governo. O corpo produtivo, destinação possível (no sentido humiano) do corpo social, corre um risco de recessão ou de estagnação, em decorrência de uma política econômica mal adaptada; o governo é, portanto, diretamente responsável pela sorte do corpo produtivo, e é a ele que se deve falar. Mas uma política de vida curta, violenta ou arbitrária pode ainda, como testemunha o exemplo da dívida pública, semear os germes da dissolução do corpo social a longo prazo, pela dissociação dos elementos do corpo produtivo, e ameaçar a economia das regras primeiras da justiça por deslocamento da propriedade. Importa, desde então, distinguir por uma análise fina os sintomas do mal e a própria doença, não tomar o efeito lateral como causa, a fim de discernir os verdadeiros fatores da saúde do corpo, "a força real de toda sociedade": o trabalho humano e a produção dos bens no "curso natural das coi- 
sas", isto é, a solidariedade dos diferentes setores de atividade. O retorno à ordem pode então tomar a forma de uma ordenação, de uma prescrição médica como artifício de artifício, que seja como artifício corretor suscetível de restabelecer o equilíbrio interno do corpo ao restituir-lhe as forças. O contrário do natural não é o artificial, mas o arbitrário; a divisão não é entre natureza e artifício, mas entre artifício perturbador e artifício facilitador, cuja eficácia deve ser apreciada em função da situação presente concebida como um certo possível advindo na natureza, na medida que esta apenas se realiza no artifício e em virtude dele. O conselho principal, endereçado pelo filósofo-conselheiro ao magistrado-executante, não é conselho de abstenção, mas de intervenção de um artifício sobre outro. $\mathrm{Na}$ ausência de critérios a priori e de uma metafísica da ordem, a intervenção só pode ter sentido e escopo ao se tomarem em consideração as "circunstâncias" presentes, necessariamente condenadas à mudança. Pois a única uniformidade mantida através da variedade temporal e espacial é a das paixões, da mecânica que as anima e do poder do artifício - numa palavra, aquilo que Hume chama de "natureza humana".

O "realismo" humiano consiste precisamente em compor com a realidade, não aceitar o estado presente da sociedade nem como fatalidade nem como realização de um desígnio superior, mas como um possível, advindo de uma combinação original de elementos que engendram seus requisitos específicos, o que exclui, de saída, toda volta ao passado e toda projeção arriscada do futuro. $\mathrm{O}$ real é o atual: se o discurso não é adequado, a observação e a reflexão são requeridas, para que surja a avaliação do gesto oportuno. O real não precisa ser constituído: está dado, ainda que seja produzido. E o trabalho do filósofo reencontra seu ponto de aplicação nesse dado cujas regras de produção cabem à ciência da natureza humana, mas que, pelo fato mesmo de que é percebido como efeito, como resultado, impede toda tentativa de formalização de sua constituição. Entre a produção e a constituição do real, tem-se a distância que separa um processo de efetuação de um procedimento de jurisdição. Do fato ao direito, há um fosso impossível de atravessar. O fato, endossado por uma jurisdição, é a emanação de uma resistência vital, um compromisso exigido pelo conflito entre o homem e a natureza; mas a substituição é ainda mais fácil. E mais exato seria dizer que o fato se sustenta por costume, em todos os atos da vida cotidiana como na vida política. O pensamento de Hume, em conformidade, talvez, ao sistema político inglês, que cria menos do que reconhece o que já está dado, que "efetua" bem menos que "constitui", é de uma ponta a outra antijurídico, ou para dizer de maneira mais adequada, na medida que não é negada a necessidade de uma jurisdição, se oferece como antijuridismo.

Passagem do particular ao geral, eu dizia no começo, como passagem do 
doméstico ao político. Mas o geral, para Hume, é a resultante da combinação das particularidades; a norma, em sua variedade e contingência, é construida em função das circunstâncias. O geral, para os fisiocratas, é ao mesmo tempo o resultado da experiência e o que se encontra determinado pelo natural-essencial; é preciso que a experiência concorde com a norma atribuída, pois a norma é instruída e restringente pela essencialidade que a habita, exterior ao agente; sua restrição vem da imposição de algo que é preordenado. A restrição da norma, estabelecida, e não dada, vem, para Hume, do fato de que ela é elaborada, inesperada e não-conforme. Entre o liberalismo dos fisiocratas e o de Hume, há toda a distância que separa a conformidade da invenção. Hume é sem dúvida conservador; reconheçamos ao menos que, neste sentido preciso, ele não é conformista. 